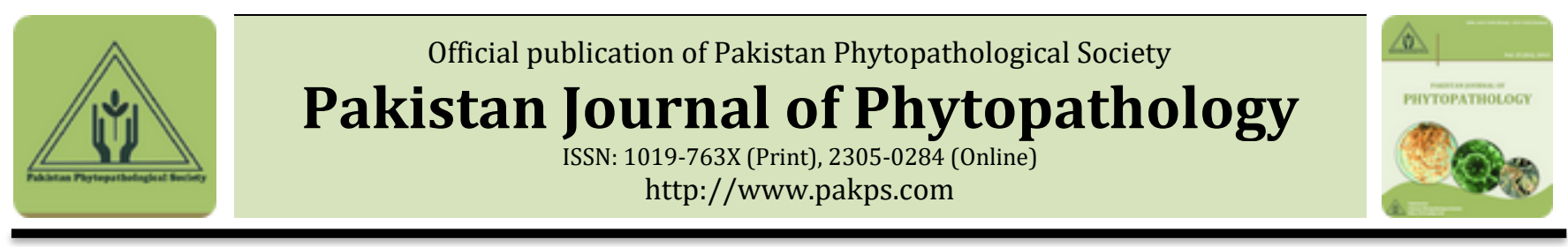

\title{
EFFECT OF PHYSIOLOGICAL PARAMETERS ON MASS PRODUCTION OF TRICHODERMA SPECIES
}

\author{
Muhammad U. Ghazanfar, Mubashar Raza, Waqas Raza*
}

Department of Plant Pathology, College of Agriculture, University of Sargodha, 40100 Sargodha, Pakistan.

\section{A B S T R A C T}

Mycophagous fungi show antagonistic potential against plant pathogenic fungi and suggested as a promising biocontrol agent that influences by nutritional and environmental parameters. The present research was conducted with the aim to determine optimal environmental and nutritional parameters range for biomass production of Trichoderma. The two species of Trichoderma isolated from rhizosphere of citrus, wheat and tomato of different localities of district Sargodha, Punjab, Pakistan and later on effect of temperature, carbon, nitrogen and $\mathrm{pH}$ were investigated on three strain of T. harzianum HM, HK, HC and one strain of T. asperellum TH under in vitro conditions. All strains produced statistically sufficient mass production at all temperatures but $25^{\circ} \mathrm{C}$ as well as $30{ }^{\circ} \mathrm{C}$ were found ideal for mass production of Trichoderma. A substantial difference in mass production of Trichoderma isolates was recorded at different $\mathrm{pH}$ levels includes 4.0, 5.0, 6.0, 7.0 and 8.0. The $\mathrm{pH}$ range from 5.0 to 7.0 found to be optimum for all species of Trichoderma. All fungal species of Tricoderma produced extensive mass production on growth media supplemented with carbon and nitrogen sources such as mannose, glactose, sucrose, lactose and sodium nitrite $\left(\mathrm{NaNO}_{3}\right)$, potassium nitrate $\left(\mathrm{KNO}_{3}\right)$, ammonium nitrate $\left(\mathrm{NH}_{4} \mathrm{NO}_{3}\right)$ as well as ammonium nitrite $\left(\mathrm{NH}_{4} \mathrm{NO}_{3}\right)$ respectively. The optimal mass production was recorded on carbon supplemented growth medium as compared to nitrogen supplemented growth medium. Therefore, T. harzianum HK produced maximum biomass production among all isolates of Trichoderma.

Keywords: Trichoderma species, biocontrol, temperature, pH, light, carbon and nitrogen sources.

\section{INTRODUCTION}

Trichoderma species are successful antagonist having biocontrol abilities against economically important plant parasitic soil borne pathogens and present abundantly in almost all types of soils (Olabiyi and Ruocco, 2013; Kushwaha et al., 2014; Shahid and Srivastava, 2014). Biocontrol antagonists play an important role in the management of plant diseases (Hajieghrari et al., 2008; Alwathnani and Perveen, 2012; Li et al., 2013). Generally, commercial production of Trichoderma largely depends upon bulk conidia production that reproduces asexually (Verma et al., 2007; Singh and Nautiyal, 2012). Mass production of Trichoderma conidia Submitted: May 01, 2018

Revised: May 25, 2018

Accepted for Publication: June 08, 2018

* Corresponding Author:

Email: waqasraza61@yahoo.com

(C) 2017 Pak. J. Phytopathol. All rights reserved. relies on physical and environmental parameters that promote conidiation for commercial production of Trichoderma species (Harman et al., 2010; Singh et al., 2014). Trichoderma species have much importance as biological control agents against plant pathogens (Monte, 2001). The environmental factors includes temperature and $\mathrm{pH}$ influences mass production as well as mycelial growth of Trichoderma and plant pathogenic fungi (Cavalcante et al., 2008; Wang et al., 2014). Among these parameters, $\mathrm{pH}$ is most imperative factor that affects the mycoparasitic activities of Trichoderma (Kredics et al., 2004). A specific and optimum value of physiological and environmental parameters is necessary for maximum growth of biocontrol agent where it can multiply and control the pathogen easily (Hajieghrari et al., 2008). Most of the studies on varying $\mathrm{pH}$ revealed that sporulation and optimum growth rate of Trichoderma ranging from 2.5 to 7.5 (Bandyopadhyay et al., 2003; Begoude et al., 2007). Trichoderma strains 
are able to grow in varying $\mathrm{pH}$ levels with maximum growth rate at $4 \mathrm{pH}$ but the optimum range for rapid growth varies from 4-7 pH (Begoude et al., 2007). So, there is need to modify Trichoderma strains genetically for acidic and saline soils where there performance can produce better results for reducing the severity level of plant pathogens. Similarly, temperature is also imperative parameter for growth and sporulation of Trichoderma species (Puyam et al., 2013). Significant information on nutrition of Trichoderma are available in literature but very little is well-known about specific carbon and nitrogen nutrients on mass production of Trichoderma antagonists (Rajput et al., 2014). Therefore, present research work conducted to study effect of different physiological parameters on mass production of Trichoderma isolates.

\section{MATERIAL AND METHODS}

Isolation and identification of Trichoderma: All isolates were collected from rhizosphere of citrus, wheat and tomato of different localities of district Sargodha, Punjab, Pakistan. Isolation was done from different soil samples on potato dextrose agar (PDA) media followed by soil dilution method.

Trichoderma inoculums preparation: Three strains of T. harzianum HM, HK, HC and one strain of T. asperellum TH were investigated on potato dextrose agar medium (potato starch 20g; dextrose 20g; agar 20g; distilled water $1000 \mathrm{ml}$ ) for biomass production (Mustafa et al., 2009). Spore suspensions of Trichoderma were prepared from 7 days mature fungal colony by addition of distilled water $(15 \mathrm{ml})$ to extricate spore from mycelial growth. The spore concentration (110 spores/ml) obtained by counting of spores with help of heamocytometer to inoculate $100 \mathrm{ml}$ TSM broth in $500 \mathrm{ml}$ flask. The cultures were incubated at $25 \pm 2^{\circ} \mathrm{C}$ in an arbitrary shaker operating at $150 \mathrm{rpm}$ for 2 days. The resultant cultures were washed aseptically with distilled water to eliminate remaining media and then used for further experiments as standard inoculum. A total $10 \%(\mathrm{v} / \mathrm{v})$ of standard inoculum was inoculated and experiment performed in triplicate. The biomass production was indication of Trichoderma growth and mycelial dry weight calculated by using oven dry method.

Effect of temperature: The species of Trichoderma were analyzed on various temperatures in order to determine optimum temperature for mass production on potato dextrose agar medium. The conical flasks contain TSM incubated at $20,25,30,35$ and $40^{\circ} \mathrm{C}$ in a shaker operating at $150 \mathrm{rpm}$ for 7 days. The optimum temperature that was supported maximum biomass production used for further subsequent steps.

Effect of carbon source: The carbon sources used in this study were mannose, glactose, sucrose and lactose. The nutrients effects on mass production were evaluated in CzepekDox Liquid Medium and medium amended with glycine $(1 \mathrm{~g} / \mathrm{L})$ or glucose $(10 / \mathrm{g} / \mathrm{L})$ and media were sterilized for 15 minutes at 15 psi, penicillin @100,000 units/lit. and streptomycine @ 0.2 g/lit. were added in media just before pouring to inhibit the bacterial growth (Rajput et al., 2015). Carbon sources were filtered sterilized and put into autoclaved media at $20 \mathrm{~g} / \mathrm{L}$. Each conical flask of $250 \mathrm{ml}$ contains $100 \mathrm{ml}$ media inoculated with Trichoderma mycelial $5 \mathrm{~mm}$ agar plug from 7 days mature fungal colony. Each treatment replicated three times and mass production of Trichoderma species was recorded after 14 days of incubation at $25 \pm 2{ }^{\circ} \mathrm{C}$.

Effect of nitrogen source: The nitrogen sources used in this study were sodium nitrite $\left(\mathrm{NaNO}_{3}\right)$, potassium nitrate $\left(\mathrm{KNO}_{3}\right)$, ammonium nitrate $\left(\mathrm{NH}_{4} \mathrm{NO}_{3}\right)$ and ammonium nitrite $\left(\mathrm{NH}_{4} \mathrm{NO}_{3}\right)$. All remaining procedures were followed as performed in carbon sources but amount of nitrogen sources as basal medium used $2 \mathrm{~g} / \mathrm{L}$ as compared to nitrogen sources.

Effect of pH: Isolates of Trichoderma species were investigated in-vitro at $\mathrm{pH} \mathrm{4,5,6,7}$ and 8. A standard inoculum was inoculated in $100 \mathrm{ml}$ TSM broth into a 500 $\mathrm{ml}$ conical flask. Inoculated flask contains TSM growth medium incubated at $25 \pm 2^{\circ} \mathrm{C}$ in an arbitrary shaker operating at $150 \mathrm{rpm}$ for 7 days. The optimum $\mathrm{pH}$ that was supported maximum biomass production used for further subsequent steps.

\section{STATISTICAL ANALYSIS}

The readings of experimental results were obtained and data analyzed with the help of statistical software $\mathrm{R}$ by using Least Significant Test (LSD). The results which have $\mathrm{P}<0.05$ were considered as significant.

\section{RESULTS}

Isolation and identification of Trichoderma: All four strains of Trichoderma selected among 15 isolates on the basis of morphological characteristics such as length, width of spores and colonies patterns in PDA plates at room temperature such as ranges from light green to dark green according to the description of Kannangara et al., 2017.

Effect of temperature: All Trichoderma species produced good amount of biomass at varying temperatures. $T$. harzianum HK produced maximum biomass (1461 mg) at 
incubation of $25^{\circ} \mathrm{C}$ as compared to $30^{\circ} \mathrm{C}$ and $20^{\circ} \mathrm{C}$ that results $1396 \mathrm{mg}$ and $1324 \mathrm{mg}$ biomass production respectively. The subsequent maximum biomass produced by $T$. harzianum HM, T. asperellum $\mathrm{TH}$ and T. harzianum $\mathrm{HC}$ at $25^{\circ} \mathrm{C}$ was $1443 \mathrm{mg}, 1221 \mathrm{mg}$ and $1158 \mathrm{mg}$ respectively. Biomass production of T. harzianum HK was high on all temperature as compared to others Trichoderma species. The statistical analysis revealed that there is no significant variation between $25^{\circ} \mathrm{C}$ and $30{ }^{\circ} \mathrm{C}$ shown in Table 1.

Table 1. Effect of temperature on biomass production of Trichoderma species

\begin{tabular}{cccccc}
\hline \multirow{2}{*}{ Temperature } & T. asperellum TH & T. harzianum HM & T. harzianum HK & T. harzianum HC & \multirow{2}{*}{ Mean \pm S.E } \\
\cline { 2 - 5 } & Mean \pm S.E & Mean \pm S.E & Mean \pm S.E & Mean \pm S.E & \\
\hline $20^{\circ} \mathrm{C}$ & $1159 \pm 1.41^{\mathrm{b}}$ & $1293 \pm 1.24^{\mathrm{c}}$ & $1324 \pm 1.00^{\mathrm{c}}$ & $1049 \pm 1.69^{\mathrm{c}}$ & $1206.7 \pm 1.3^{\mathrm{C}}$ \\
\hline $25^{\circ} \mathrm{C}$ & $1216 \pm 1.34^{\mathrm{a}}$ & $1443 \pm 1.65^{\mathrm{a}}$ & $1461 \pm 0.90^{\mathrm{a}}$ & $1158 \pm 1.15^{\mathrm{a}}$ & $1319.9 \pm 1.2^{\mathrm{A}}$ \\
\hline $30^{\circ} \mathrm{C}$ & $1220 \pm 1.23^{\mathrm{a}}$ & $1369 \pm 1.75^{\mathrm{b}}$ & $1396 \pm 1.23^{\mathrm{b}}$ & $1100 \pm 1.53^{\mathrm{b}}$ & $1271.7 \pm 1.4^{\mathrm{B}}$ \\
\hline $35^{\circ} \mathrm{C}$ & $901 \pm 1.98^{\mathrm{c}}$ & $1129 \pm 1.12^{\mathrm{d}}$ & $1171 \pm 1.00^{\mathrm{d}}$ & $782 \pm 1.8^{\mathrm{d}}$ & $996.2 \pm 1.4^{\mathrm{D}}$ \\
\hline $40^{\circ} \mathrm{C}$ & $583 \pm 2.36^{\mathrm{d}}$ & $647 \pm 1.36^{\mathrm{e}}$ & $700 \pm 1.20^{\mathrm{e}}$ & $509 \pm 1.16^{\mathrm{e}}$ & $610.0 \pm 1.5^{\mathrm{E}}$ \\
\hline Mean & $1016.4 \pm 1.64^{\mathrm{C}}$ & $1176.5 \pm 1.42^{\mathrm{B}}$ & $1210.8 \pm 1.06^{\mathrm{A}}$ & $919.5 \pm 1.46^{\mathrm{D}}$ & \\
\hline
\end{tabular}

${ }^{*}$ Small letters are for comparison within column comparison, Capital letters for comparison for comparison among temperature mean, Bold and capital letters are for comparison among species.

Effect of carbon source: Trichoderma biomass in different carbon amended media was significantly superior than nitrogen amended nutrition. Mannose is best carbon nutritional medium for Trichoderma among the carbon sources followed by glactose, sucrose and lactose. All species of Trichoderma produced dark green and yellow greenish conidia with prominent concentric rings on lactose, sucrose and mannose respectively. Trichoderma harzianum $\mathrm{HK}$ biomass production was maximum (1627.2 mg) among Trichoderma strains on carbon sources followed by T. harzianum HM (1571.0 $\mathrm{mg})$, T. asperellum TH (1505.6 mg) and T. harzianum HC (1427.1 mg) while all Trichoderma strains produced maximum biomass on mannose $(2604.5 \mathrm{mg}$ ) followed by glactose (2310.2 mg), sucrose (1967.8 $\mathrm{mg}$ ) and lactose (440.1 mg). The statistical analysis revealed clear differences among Trichoderma biomass production on different carbons sources in Table 2 .

Table 2. Effect of carbon sources on biomass production of Trichoderma species

\begin{tabular}{cccccc}
\hline Carbon & T. asperellum TH & T. harzianumHM & T. harzianumHK & T. harzianumHC & \multirow{2}{*}{ Mean \pm S.E } \\
\cline { 2 - 5 } Sources & Mean \pm S.E & Mean \pm S.E & Mean \pm S.E & Mean \pm S.E & \\
\hline Control & $305.8 \pm 0.88^{\mathrm{e}}$ & $375.0 \pm .97^{\mathrm{e}}$ & $432.4 \pm 1.23^{\mathrm{e}}$ & $247.1 \pm 1.51^{\mathrm{e}}$ & $340.1 \pm 1.14^{\mathrm{E}}$ \\
\hline Glactose & $2274.6 \pm 1.17^{\mathrm{b}}$ & $2329.0 \pm 1.21^{\mathrm{b}}$ & $2425 \pm 1.34^{\mathrm{b}}$ & $2211.8 \pm 1.27^{\mathrm{b}}$ & $2310.2 \pm 1.29^{\mathrm{B}}$ \\
\hline Lactose & $435.6 \pm 0.89^{\mathrm{d}}$ & $500.4 \pm .78^{\mathrm{d}}$ & $452 \pm 1.06^{\mathrm{d}}$ & $371.6 \pm 1.46^{\mathrm{d}}$ & $440.1 \pm 1.04^{\mathrm{D}}$ \\
\hline Mannose & $2571.9 \pm 1.09^{\mathrm{a}}$ & $2638.2 \pm 1.14^{\mathrm{a}}$ & $2709 \pm 1.31^{\mathrm{a}}$ & $2502 \pm 1.52^{\mathrm{a}}$ & $2605.4 \pm 1.26^{\mathrm{A}}$ \\
\hline Sucrose & $1940.0 \pm 1.33^{\mathrm{c}}$ & $2012.6 \pm 1.29^{\mathrm{c}}$ & $2115 \pm 1.17^{\mathrm{c}}$ & $1802 \pm 1.86^{\mathrm{c}}$ & $1967.8 \pm 1.41^{\mathrm{C}}$ \\
\hline Mean \pm S.E & $1505.6 \pm 1.07^{\mathrm{C}}$ & $1571.0 \pm 1.07^{\mathrm{B}}$ & $1627.2 \pm 1.2^{\mathrm{A}}$ & $1427.1 \pm 1.52^{\mathrm{D}}$ & \\
\hline
\end{tabular}

*Small letters are for comparison within column comparison, Capital letters for comparison among carbon sources mean, Bold and capital letters are for comparison among species.

Effect of nitrogen source: Trichoderma biomass in different nitrogen amended media was significantly lower than carbon amended nutrition. Sodium nitrite $\left(\mathrm{NaNO}_{2}\right)$ is statistically best nitrogen nutritional medium for Trichoderma among the nitrogen sources followed as potassium nitrate $\left(\mathrm{KNO}_{3}\right)$, ammonium nitrate $\left(\mathrm{KH}_{4} \mathrm{NO}_{3}\right)$ and ammonium nitrite $\left(\mathrm{NH}_{4} \mathrm{NO}_{2}\right)$. All species of Trichoderma produced dark green and light dark green conidia with prominent concentric rings on $\mathrm{KNO}_{3}$,
$\mathrm{KH}_{4} \mathrm{NO}_{3}$ and $\mathrm{NaNO}_{2}$ respectively. Trichoderma harzianum HK biomass production was maximum $(29.95$ mg) among Trichoderma strains on nitrogen sources followed by T. harzianum HM (22.42 mg), T. asperellum TH (19.73 mg) and T. harzianum HC (16.55 mg) while all Trichoderma strains produced maximum biomass on $\mathrm{NaNO}_{2}$ (41.47 mg) followed by $\mathrm{KNO}_{3}(28.72 \mathrm{mg}$ ), $\mathrm{KH}_{4} \mathrm{NO}_{3}(20.75 \mathrm{mg})$ and $\mathrm{NH}_{4} \mathrm{NO}_{2}(0.00 \mathrm{mg}) . \mathrm{NH}_{4} \mathrm{NO}_{2}$ found to be toxic to all Trichoderma used strains. 
Table 3: Effect of nitrogen sources on biomass production of Trichoderma species

\begin{tabular}{|c|c|c|c|c|c|}
\hline \multirow{2}{*}{ Nitrogen Sources } & T. asperellum TH & T. harzianum HM & T. harzianum HK & T. harzianum HC & \multirow{2}{*}{ Mean \pm S.E } \\
\hline & Mean \pm S.E & Mean \pm S.E & Mean \pm S.E & Mean \pm S.E & \\
\hline Control & $15.44 \pm 0.47^{d}$ & $18.22 \pm 0.46^{\mathrm{d}}$ & $22.44 \pm 0.67^{d}$ & $13.44 \pm 0.44^{\mathrm{d}}$ & $17.39 \pm .51^{\mathrm{D}}$ \\
\hline $\mathrm{KNO}_{3}$ & $27.56 \pm 0.44^{b}$ & $29.56 \pm 0.56^{b}$ & $36.11 \pm 0.89^{b}$ & $21.67 \pm 0.47$ b & $28.72 \pm .59^{\mathrm{B}}$ \\
\hline $\mathrm{NaNO}_{2}$ & $37.44 \pm 0.60^{a}$ & $44.33 \pm 0.93^{a}$ & $53.78 \pm 0.66^{a}$ & $30.33 \pm 0.53^{a}$ & $41.47 \pm .68^{\mathrm{A}}$ \\
\hline $\mathrm{NH}_{4} \mathrm{NO}_{2}$ & $0.00 \pm 0.00^{\mathrm{e}}$ & $0.00 \pm 0.00^{\mathrm{e}}$ & $0.00 \pm 0.00 \mathrm{e}$ & $0.00 \pm 0.00 \mathrm{e}$ & $0.00 \pm 0.0^{\mathrm{E}}$ \\
\hline $\mathrm{KH}_{4} \mathrm{NO}_{3}$ & $18.22 \pm 0.46^{c}$ & $20.00 \pm 0.65^{c}$ & $27.44 \pm 0.65^{c}$ & $27.44 \pm 0.41^{c}$ & $20.75 \pm .54^{\mathrm{C}}$ \\
\hline Mean \pm S.E & $19.733 \pm 0.39^{\mathrm{C}}$ & $22.42 \pm 0.52^{\mathrm{B}}$ & $27.95 \pm 0.57^{\mathrm{A}}$ & $16.55 \pm 0.37^{D}$ & \\
\hline
\end{tabular}

*Small letters are for comparison within column comparison, Capital letters for comparison among nitrogen sources mean, Bold and capital letters are for comparison among species.

The statistical analysis revealed clear differences among Trichoderma biomass production on different nitrogen sources in Table 3.

Effect of pH on biomass production of

Trichoderma species: Biomass production of Trichoderma spp. was observed at $\mathrm{pH} 4, \mathrm{pH} 5$, pH 6, pH7 and pH 8 described in table 4 with three days intervals includes 4 days, 7 days and
10 days. All species produced maximum biomass production at $7 \mathrm{pH}$ followed by $6,5,8$ and $4 \mathrm{pH}$ value. Biomass production of all species at the end of experiment (at 10 days) was ranged from 926-1128 $\mathrm{mg}$ and species showed considerable increase in biomass as time increases at all $\mathrm{pH}$ levels. The best $\mathrm{pH}$ range was recorded from 6-7 for maximum biomass production. The mass production of $T$. asperellum TH was low as compared to $T$. harzianum rather than T. harzianum HC while comparing within T. harzianum strains (HM, HK and HC) showed T. harzianum HK produced higher biomass followed by T. harzianum HM and T. harzianum HC. The statistical analysis revealed that there is no significant variation between pH 6 and 7 in table 4 .

Table 4: Effect of $\mathrm{pH}$ on bio mass production of Trichodrma spp.

\begin{tabular}{|c|c|c|c|c|c|c|c|c|c|c|c|c|c|}
\hline \multirow{2}{*}{$\begin{array}{c}\mathrm{pH} \\
\text { levels }\end{array}$} & \multicolumn{3}{|c|}{ T. asperellum } & \multicolumn{3}{|c|}{ T. harzianumHM } & \multicolumn{3}{|c|}{ T. harzianumHK } & \multicolumn{3}{|c|}{ T. harzianumHC } & \multirow[t]{2}{*}{ Mass } \\
\hline & $4^{\text {th }}$ days & $7^{\text {th }}$ days & $10^{\text {th }}$ days & $4^{\text {th }}$ days & $7^{\text {th }}$ days & $10^{\text {th }}$ days & $4^{\text {th }}$ days & $7^{\text {th }}$ days & $10^{\text {th }}$ days & $4^{\text {th }}$ days & $7^{\text {th }}$ days & $10^{\text {th }}$ days & \\
\hline $4 \mathrm{pH}$ & $411.2 \pm 1.8^{c}$ & $497.0 \pm 1.5^{\mathrm{e}}$ & $598.3 \pm 1.2^{\mathrm{e}}$ & $\underset{\mathrm{d}}{425.9 \pm 1.2}$ & $613.4 \pm 1.3^{c}$ & $704.6 \pm 1.9^{\mathrm{e}}$ & $446.5 \pm 1.0^{\mathrm{e}}$ & $678.6 \pm 1.2^{\mathrm{c}}$ & $787.4 \pm 1.3^{\mathrm{e}}$ & $\underset{\mathrm{e}}{262.2 \pm 1.2}$ & $431.3 \pm 1.0^{\mathrm{e}}$ & $541.4 \pm 0.8^{\mathrm{e}}$ & $533.2 \pm 1.3^{\mathrm{B}}$ \\
\hline $5 \mathrm{pH}$ & $784.2 \pm 2.9^{c}$ & $886.0 \pm 2.4^{\mathrm{c}}$ & $991.0 \pm 1.8^{c}$ & $\begin{array}{c}773.4 \pm 1.0 \\
\text { b }\end{array}$ & $\begin{array}{c}1003.7 \pm 1.4 \\
\mathrm{c}\end{array}$ & $\begin{array}{c}1106.1 \pm 1.7 \\
\mathrm{c}\end{array}$ & $801.7 \pm 1.0^{\mathrm{e}}$ & $1033.4 \pm 1.5^{\mathrm{e}}$ & $1132.4 \pm 1.5^{c}$ & $\begin{array}{c}701.4 \pm 1.5 \\
\mathrm{c}\end{array}$ & $807 \pm 1.3^{c}$ & $910.0 \pm 1.7^{c}$ & $910.9 \pm 1.7^{\mathrm{C}}$ \\
\hline $6 \mathrm{pH}$ & $88.2 \pm 3.2^{\mathrm{b}}$ & $\begin{array}{c}1155.3 \pm 3.6 \\
\mathrm{e}\end{array}$ & $\begin{array}{c}1233.4 \pm 2.0 \\
\mathrm{~b}\end{array}$ & $\begin{array}{c}985.0 \pm 1.1 \\
\mathrm{a}\end{array}$ & $\begin{array}{c}1199.4 \pm 1.7 \\
\text { b }\end{array}$ & $\begin{array}{c}1290.2 \pm 1.2 \\
\mathrm{a}\end{array}$ & $1013 \pm 1.1^{\mathrm{b}}$ & $1272.7 \pm 1.3^{\mathrm{b}}$ & $1332.4 \pm 1.6^{a}$ & $\begin{array}{c}782.0 \pm 1.3 \\
\mathrm{~b}\end{array}$ & $\begin{array}{c}1039.7 \pm 1.7 \\
\text { b }\end{array}$ & $\begin{array}{c}1134.4 \pm 1.3 \\
\mathrm{~b}\end{array}$ & $1110.5 \pm 1.8^{\mathrm{B}}$ \\
\hline $7 \mathrm{pH}$ & $\begin{array}{c}989.8 \pm 2.3 \\
\mathrm{a}\end{array}$ & $\begin{array}{c}1268.8 \pm 1.9 \\
\text { a }\end{array}$ & $\begin{array}{c}1325.2 \pm 2.2 \\
\mathrm{a}\end{array}$ & $\begin{array}{c}992.1 \pm 1.4 \\
\mathrm{a}\end{array}$ & $\begin{array}{c}1225.8 \pm 1.6 \\
a\end{array}$ & $\begin{array}{c}1199.7 \pm 1.2 \\
\mathrm{c}\end{array}$ & $\begin{array}{c}1108.2 \pm 1.8 \\
\mathrm{c}\end{array}$ & $1283.9 \pm 1.2^{\mathrm{a}}$ & $1316.7 \pm 0.9^{e}$ & $\begin{array}{c}891.3 \pm 1.6 \\
\mathrm{a}\end{array}$ & $\begin{array}{c}1251.6 \pm 1.4 \\
\mathrm{a}\end{array}$ & $\begin{array}{c}1308.7 \pm 1.2 \\
\mathrm{a}\end{array}$ & $\underset{\mathrm{A}}{1130.6 \pm 1.57}$ \\
\hline $8 \mathrm{pH}$ & $\begin{array}{c}490.0 \pm 1.4 \\
\mathrm{~d}\end{array}$ & $782.3 \pm 3.4^{\mathrm{d}}$ & $847.9 \pm 1.4^{\mathrm{d}}$ & $\begin{array}{c}489.9 \pm 1.5 \\
\mathrm{c}\end{array}$ & $\begin{array}{c}817.9 \pm 1.46 \\
\mathrm{~d}\end{array}$ & $898.7 \pm 1.3^{\mathrm{d}}$ & $503.1 \pm 1.1^{\mathrm{d}}$ & $1000.3 \pm 1.7 \mathrm{e}$ & $1073.0 \pm 2.4^{\mathrm{e}}$ & $\begin{array}{c}372.8 \pm 1.3 \\
\mathrm{~d}\end{array}$ & $673.1 \pm 2.8^{\mathrm{d}}$ & $736.1 \pm 1.4^{\mathrm{d}}$ & $723.7 \pm 1.8^{\mathrm{D}}$ \\
\hline $\begin{array}{c}\text { Mea } \\
\mathrm{n}\end{array}$ & $712.6 \pm 2.3$ & $837.6 \pm 2.6$ & $998.8 \pm 1.7$ & $732.8 \pm 1.2$ & $972.04 \pm 1.5$ & $109.86 \pm 1.4$ & $777 \pm 1.2$ & $\begin{array}{c}1054.78 \pm 1 \\
4\end{array}$ & $\begin{array}{c}1128.38 \pm 1 \\
5\end{array}$ & $601.9 \pm 1.4$ & $340.5 \pm 1.6$ & $926.12 \pm 1.4$ & \\
\hline
\end{tabular}

\section{DISCUSSION}

The physiological parameters play an important role in enhancing mycelial growth and biomass production of Trichoderma species its Growth and multiplication of biocontrol agents varies with the substrates (Gao et al., 2007; Romero-Arenas et al., 2012). Many researchers reported that temperature, $\mathrm{pH}$ are key environmental factors that influence Trichoderma bio mass production (Kredics et al., 2003; Steyaert et al., 2010; Steyaert et al., 2010a; Steyaert et al., 2010b; CarrerasVillaseñor et al., 2012). The influence of $\mathrm{pH}$ on biomass and mycelial growth demonstrated that acidic $\mathrm{pH}$ is most important key factor for 
biomass production of all Trichodemra species (Singh et $a l, 2014$ ) and they modify the rhizosphere by acidifying the soil which results in unfavorable conditions for growth of plant pathogens (Limón et al., 2004). The present study confirmed that species of Trichoderma produced more biomass or grow better in acidic environment. Acidic pH (6.5) is most favorable environment for fungal growth rather than basic or alkaline pH (Limon et al., 2004; Singh et al., 2014) Our experiments demonstrate that all Trichoderma species produce higher biomass production at $\mathrm{pH}$ range 5-7 rather than $\mathrm{pH} 8$ and hardly some species of Trichoderma seems to be tolerate at $\mathrm{pH}$ lower than 3 . However, it is more difficult to associate fungal activities in laboratory growth media at low $\mathrm{pH}$ with their activities in field conditions or natural habitat where $\mathrm{pH}$ effecting microbial activities (Claudia, 2007).

Among environmental parameters, temperature is generally regarded as important factor that also affects Trichoderma biomass production. Sharma et al., (2005) studied the effect of temperatures and reported that none of the Trichoderma species grew at above or at 40 ${ }^{\circ} \mathrm{C}$. Our study revealed that increase in temperature range from $30{ }^{\circ} \mathrm{C}$ reduces the biomass production and 25 ${ }^{\circ} \mathrm{C}$ to $30{ }^{\circ} \mathrm{C}$ found to be best for Trichoderma growth and biomass production. As temperature seemed to have very adverse effect on the viability of the isolates to produce non-volatile inhibitors and inhibition zone has been found to observe great eat at optimum temperatures which results in increase bio mass production as confirmed by Tronsmo et al., 1978; Singh et al., 2014.

In additions, selected carbon and nitrogen sources found to be most suitable substrates significantly enhanced growth and population of Trichodermas pecies (Kredicset al., 2003). Among the selected carbon and nitrogen sources found to be most effective for growth and multiplication of Trichoderma may be due to Fungi use a large number of organic compounds as a carbon sources and about half of the dry weight of the fungus cells consists of carbon, which gives an indication of the important role of carbon compounds within the cell (Singh et al., 2012; Rai et al., 2016).

\section{CONCLUSION}

Isolation and morphological characterization are the important tools that leads to further steps for Trichoderma biomass production at different nutritional and environmental parameters. A present study was conducted at varying temperature, $\mathrm{pH}$ as well as different carbon and nitrogen nutritional sources for biomass production of Trichoderma species in order to find out most favorable and relevant parameter. Trichoderma biomass and multiplication was most favored by $25^{\circ} \mathrm{C}$ while $30^{\circ} \mathrm{C}$ was moderately effective and growth was reduced above $30^{\circ} \mathrm{C}$. Correspondingly, pH 7 found to best and biomass production closely related to $\mathrm{pH} 7$ at $\mathrm{pH} 6$ while growth and biomass reduces at $\mathrm{pH} 8$ due to growth of Trichoderma is more efficient in acidic than alkaline soils and they modify the rhizosphere soil by acidifying the soil.

Among the tested sources, mannose, glactose and sucrose found to be most suitable carbon sources for all $T$. harzianum HM, HK, $\mathrm{HC}$ and $T$. asperellum used. Lactose showed no significant biomass as compared to control. Similarly, Sodium nitrate was found to be the best nitrogen source for all Trichoderma strains. In the present study, all Trichoderma strains produce maximum biomass production on carbon emended media and found to best for its multiplication. $T$. harzianum HK produce maximum biomass on carbon and nitrogen sources at $\mathrm{pH}$ and temperature ranges to 57 and $25^{\circ} \mathrm{C}-30^{\circ} \mathrm{C}$ respectively. It can be further promoted for production of commercial formulation against soil borne fungal pathogens.

\section{REFERENCES}

Alwathnani, H. A. and K. Perveen. 2012. Biological control of fusarium wilt of tomato by antagonist fungi and cyanobacteria. African Journal of Biotechnology, 11:1100-1105.

Bandyopadhyay, S., S. Jash and S. Dutta. 2003. Effect of different $\mathrm{pH}$ and temperature levels on growth and sporulation of Trichoderma. Environment and Ecology, 21: 770-773.

Begoude, B. A. D., R. Lahlali, D. Friel, P. R. Tondje and M. H. Jijakli. 2007. Response surface methodology study of the combined effects of temperature, $\mathrm{pH}$, and on the growth rate of Trichoderma asperellum. Journal of Applied Microbiology, 103: 845-854.

Carreras-Villaseñor, N., J. A. Sánchez-Arreguín and A. H. Herrera-Estrella. 2012. Trichoderma: sensing the environment for survival and dispersal. Microbiology, 158: 3-16.

Cavalcante, R. S., H. L. Lima, G. A. Pinto, C. A. Gava and S. Rodrigues. 2008. Effect of moisture on 
Trichoderma conidia production on corn and wheat bran by solid state fermentation. Food and Bioprocess Technology, 1: 100-104.

Claudia, M. O. L. 2007. Fungal biocontrol agents: identification and fate of Trichoderma atroovitide P. Karst In the environment. p. 70.

Gao, S. P., K. G. Mark, K. Leslie, W. Pao, N. Motoi, W. L. Gerald, W. D. Travis, W. Bornmann, D. Veach and B. Clarkson. 2007. Mutations in the EGFR kinase domain mediate STAT3 activation via IL-6 production in human lung adenocarcinomas. The Journal of clinical investigation, 117: 3846-3856.

Hajieghrari, B., M. Torabi-Giglou, M. R. Mohammadi and M. Davari. 2008. Biological potantial of some Iranian Trichoderma isolates in the control of soil borne plant pathogenic fungi. African Journal of Biotechnology, 7: 967-972.

Harman, G. E., M. A. Obregón, G. J. Samuels and M. Lorito. 2010. Changing Models for Commercialization and Implementation of Biocontrol in the Developing and the Developed World. Plant Disease, 94: 928939.

Kannangara, S., R. M. G. C. S. Dharmarathna and D. L. Jayarathna. 2017. Isolation, Identification and Characterization of Trichoderma Species as a Potential biocontrol agent against Ceratocystis paradoxa. Journal of Agricultural Sciences, 12: 5162.

Kredics, L., L. Manczinger, Z. Antal, Z. Penzes, A. Szekeres, F. Kevei and E. Nagy. 2004. In vitro water activity and $\mathrm{pH}$ dependence of mycelial growth and extracellular enzyme activities of Trichoderma strains with biocontrol potential*. Journal of Applied Microbiology, 96: 491-498.

Kredics, L., Z. Antal, L. Manczinger, A. Szekeres, F. Kevei and E. Nagy. 2003. Influence of environmental parameters on Trichoderma strains with biocontrol potential. Food Technology and Biotechnology, 41: 37-42.

Kushwaha, M., A. K. Verma, M. Alauddin, A. P. Choudhary, V. K. Mishra and R. Goswami. 2014. Antagonistic activity of Trichoderma spp, (a bio-control agent) against isolated and identified plant pathogens. International Journal of Chemical and Biological Sciences, 1: 1-6.

Li, S., N. Zhang, Z. Zhang, J. Luo, B. Shen, R. Zhang and Q. Shen. 2013. Antagonist Bacillus subtilis HJ5 controls Verticillium wilt of cotton by root colonization and biofilm formation. Biology and fertility of soils, 49: 295-303.

Limon, M. C., M. R. Chacon, R. Mejoas, J. Delgado-Jarana, A. M. Rincon, A. C. Codon and T. Benotez. 2004. Increased antifungal and chitinase specific activities of Trichoderma harzianum CECT 2413 by addition of a cellulose binding domain. Applied Microbiology and Biotechnology, 64: 675-685.

Monte, E. 2001. Understanding Trichoderma: between biotechnology and microbial ecology. International Microbiology, 4: 1-4.

Mustafa, A., M. A. Khan, M. Inam-ul-Haq, M. A. Pervez and U. Umar. 2009. Usefulness of different culture media for in vitro evaluation of Trichoderma spp. against seed borne fungi of economic importance. Pakistan Journal Phytopathology, 21: 83-88.

Olabiyi, T. I. and M. Ruocco. 2013. In-vitro Competition Bio-assay Experiment on the Effect of Trichoderma Species and Some Crop Pathogenic Fungi. In-vitro, 3.

Puyam, A., M. Srivastava and A. Singh. 2013. Effect of different physiological parameters on growth and sporulation of Trichoderma viride. Plant Disease Research, 28: 146-151.

Rai, D. A., K. Tewari. 2016. Evaluation of different carbon and nitrogen sources for better growth and sporulation of $T$. harzianum (Th14). Journal of Agricultural Biotechnology and Sustainable Development, 8: 67-70.

Rajput, A. Q. and S. Shahzad. 2015. Growth and sporulation of Trichoderma polysporum on organic substrates by addition of carbon and nitrogen sources. Pakistan Journal of Botany, 47: 979-986.

Rajput, A., M. Khanzada and S. Shahzad. 2014. Effect of different organic substrates and carbon and nitrogen sources on growth and shelf life of Trichoderma harzianum. Journal of Agricultural Science and Technology, 16: 731-745.

Romero-Arenas, O., M. A. D. Huato, I. H. Trevintilde, J. P. Lezama, A. A. García and A. D. V. Arellano. 2012. Effect of $\mathrm{pH}$ on growth of the mycelium of Trichoderma viride and Pleurotus ostreatus in solid cultivation mediums. African Journal of Agricultural Research, 7: 4724-4730.

Shahid, M. and M. Srivastava. 2014. Comparative Study of Biological Agents, Trichoderma harzianum (ThAzad) and Trichoderma viride (01PP) for Controlling Wilt Disease in Pigeon Pea. Journal of 
Microbial \& Biochemical Technology, 06: 110-115. Sharma, R., B. Singh, M. Thakur and S. Thapak. 2005. Effect of media, temperature, $\mathrm{pH}$ and Light on the growth and sporulation of Fusarium oxysporum $\mathrm{f}$. sp. lini (Bolley) Snyder and Hensan. Annals of Plant Protection Sciences, 13: 172-174.

Singh, A., M. Shahid, M. Srivastava, S. Pandey, A. Sharma and V. Kumar. 2014. Optimal physical parameters for growth of Trichoderma species at varying $\mathrm{pH}$, temperature and agitation. Virology and Mycology, 3: 1-7.

Singh, P. C. and C. S. Nautiyal. 2012. A novel method to prepare concentrated conidial biomass formulation of Trichoderma harzianum for seed application. Journal of Applied Microbiology, 113: 1442-1450.

Steyaert, J. M., R. J. Weld and A. Stewart. 2010. Ambient $\mathrm{pH}$ intrinsically influences Trichoderma conidiation and colony morphology. Fungal Biology, 114: 198-208.
Steyaert, J. M., R. J. Weld and A. Stewart. 2010. Isolatespecific conidiation in Trichoderma in response to different nitrogen sources. Fungal Biology, 114: 179-188.

Steyaert, J. M., R. J. Weld, L. L. Loguercio and A. Stewart. 2010. Rhythmic conidiation in the blue-light fungus Trichoderma pleuroticola. Fungal Biology, 114: 219-223.

Tronsmo, A. and C. Dennis. 1978. Effect of temperature on antagonistic properties of Trichoderma species. Transactions of the British Mycological Society, 71: 469-474.

Verma, M., S. K. Brar, R. Tyagi, R. Surampalli and J. Valero. 2007. Antagonistic fungi, Trichoderma spp.: panoply of biological control. Biochemical Engineering Journal, 37: 1-20.

Wang, Z.-Y., K.-L. He, F. Zhang, X. Lu and D. Babendreier. 2014. Mass rearing and release of Trichogramma for biological control of insect pests of corn in China. Biological Control, 68: 136-144. 